\title{
Prediksi Keterlambatan Penerbangan Menggunakan Metode Decision Tree Untuk Penentuan Premi Asuransi Perjalanan
}

\author{
Shella Lolitha'), Samuel Lukas ${ }^{2)}$, \& Frans Panduwinata ${ }^{3)}$ \\ ${ }^{1,2,3)}$ Program Studi Informatika, Fakultas Ilmu Komputer \\ Universitas Pelita Harapan \\ MH Thamrin Boulevard 1100, Tangerang, Banten 15811 \\ Telp (021) 5460901 \\ Mobile: $\left.{ }^{1)} 0812-9697-9780,{ }^{2}\right) 0817-6356-565,{ }^{3} 0813-9932-7582$ \\ Website https://www.uph.edu/, E-mail: SL2062@student.uph.edu ${ }^{1)}$, samuel.lukas@uph.edu ${ }^{2)}$, \\ \& frans.panduwinata@uph.edu ${ }^{3)}$
}

\begin{abstract}
Abstrak - Keterlambatan penerbangan menjadi suatu masalah yang tidak dapat dihindari pada penerbangan komersial. Kompensasi yang diatur dalam Peraturan Menteri dinilai tidak sebanding dengan keterlambatan yang terjadi. Sebaliknya, pihak perusahaan maskapai juga enggan untuk meningkatkan kualitas pel ayanan, salah satu ala sannya adalah membayar biaya kompensasi penumpang jauh lebih murah dibanding biaya yang diperlukan untuk meningkatkan pelayanan. Maka dari itu diperlukan sebuah sistem untuk penghitungan jumlah premi yang dapat dibayar oleh penumpang agar menguntungkan kedua belah pihak. Dengan menggunakan metode penghitungan statistik dan algoritma machine learning yaitu pohon keputusan, keterlambatan dapat diprediksi berdasarkan kategori keterlambatan yang tertulis dalam Peraturan Menteri dan premi asuransi dapat dihitung dengan sesuai dan saling menguntungkan kedua belah pihak. Tahap perancangan sistemadalah sebagai berikut: membaca data mentah penerbangan komersial di Indonesia dari tahun 2017 sampai 2019, melakukan preprocessing data, melakukan pe mbersihan data, melakukan pelatihan data, melakukan proses prediksi, melakukan kalkulasi premi dan membuat visualisasi untuk menampilkan hasil prediksi dan harga premi. Hasil pengujian berdasarkan matriks confusion menunjukkan bahwa model untuk memprediksi keterlambatan memiliki akurasi sebesar 72,76\%. Kemudian dari proses validasi, didapatkan bahwa tingkat kemiripan hasil prediksi dengan hasil validasi tersebut adalah 96,14\%. Hasil penghitungan premi memiliki nilai premi yang lebih masuk akal dan menguntungkan bagi penumpang penerbangan.
\end{abstract}

Kata kunci: Pohon Keputusan, Perhitungan Premi, Keterlambatan Penerbangan, Asuransi Perjalanan

\begin{abstract}
Flight delays become an inevitable issue on flight commercial. Compensation regulated in the Ministerial Regulation considered disproportionate with occurring delays. Otherwise, airline company party are also reluctant to improve the quality of service, one of the reason is pay compensation cost for passenger is much less expensive than the cost for improving services. Therefore, a system needed for calculating the amount of premium that can be paid by passengers to benefit both parties. By using statistical calculation method and machine learning algorithm, Decision Tree, delays can be predicted based on category of delays regulated in the Ministerial Regulation and insurance premium can be calculated accordingly and mutually beneficial to both parties. Phase of system design is as follows: read flight commercial in Indonesia from year 2017 to 2019 raw data, preprocess data, cleanse data, train data, process prediction, calculate premium and build visualization for presenting prediction result and premium price. Test result based on confusion matrix shows that model for predicting delays has an accuracy of $72.76 \%$. Then from validation process, it obtained that similarity level of prediction result to validation result is $96.14 \%$. The premium calculation result has premium value that is more reasonable and profitable for passengerflight.
\end{abstract}

Keywords: Decision Tree, Premium Calculation, Flight Information, Travel Insurance

\section{PENDAHULUAN}

Perkembangan transportasi penerbangan di Indonesia terus mengalami peningkatan sejak tahun 2003 [1]. Banyak masyarakat kini melakukan perjalanan dengan menggunakan jasa penerbangan komersial di Indonesia. Terdapat banyak faktor mengapa transportasi penerbangan komersial se semakin populer dan diminati masyarakat. Salah satu faktor utama adalah waktu karena waktu sangat diperhitungkan dalam dunia 
transportasi. Ketika menggunakan transportasi penerbangan menggunakan pesawat udara, waktu yang diperlukan untuk menempuh jarak tertentu menjadi lebih singkat. Faktor lainnya adalah keamanan yang erat kaitannya dengan kecelakaan. Tingkat kecelakaan fatal pesawat udara di seluruh dunia terus mengalami penurunan dari tahun ke tahun [2]. Hal ini menjadi salah satu bukti bahwa moda transportasi dengan menggunakan pesawat udara adalah transportasi yang paling aman saat ini. Namun di sisi lain, penerbangan komersial juga memiliki beberapa kekurangan yang membuat masyarakat memperhitungkan kembali dalam melakukan perjalanan menggunakan pesawat udara. Beberapa masyarakat berpendapat bahwa menggunakan transportasi pesawat udara berisiko lebih tinggi dibanding transportasi lainnya. Salah satu risiko dalam transportasi pesawat udara adalah cuaca, karena cuaca dapat menjadi ancaman keselamatan apabila terjadi perubahan cuaca secara signifikan dalam waktu yang singkat. Kemudian hal-hal yang sangat membuat masyarakat enggan menggunakan transportasi pesawat udara, yaitu keterlambatan dan pembatalan penerbangan. Terdapat banyak faktor yang dapat menyebabkan keterlambatan. Selain faktor cuaca, terdapat faktor lain seperti faktor manajemen penerbangan, keterlambatan pilot, co-pilot, atau awak kabin dan ketidaksiapan pesawat udara. Faktor lainnya adalah faktor teknis operasional, seperti bandar udara untuk keberangkatan dan tujuan tidak dapat digunakan untuk operasional pesawat udara, terjadinya antrian pesawat udara lepas landas atau mendarat, dan keterlambatan pengisian bahan bakar. Hal ini menyebabkan kerugian waktu yang cukup besar kepada penumpang pesawat udara. Peraturan Menteri Perhubungan Republik Indonesia Nomor 89 Tahun 2015 tentang Penanganan Keterlambatan (Delay Management) Pada Badan Usaha Angkutan Udara Niaga Berjadwal di Indonesia mengatur bahwa setiap badan usaha angkutan udara wajib memberikan kompensasi sesuai dengan kategori keterlambatan [3]. Namun kompensasi yang diatur dalam Peraturan Menteri tersebut dinilai tidak sebanding atau tidak memadai dengan keterlambatan yang terjadi. Sebaliknya, pihak badan usaha angkutan udara atau perusahaan maskapai juga enggan untuk meningkatkan kualitas pelayanan, salah satu alasannya adalah membayar biaya kompensasi penumpang jauh lebih ringan dibanding biaya yang diperlukan untuk meningkatkan pelayanan. Dilatarbelakangi oleh hal tersebut, diperlukan sebuah sistem untuk penghitungan jumlah premi yang dapat dibayar oleh penumpang agar menguntungkan kedua belah pihak. Ketika penumpang membeli tiket penerbangan disertai dengan pembelian premi asuransi perjalanan, pihak maskapai dapat menerima dana tambahan untuk meningkatkan layanan maskapai. Dengan menggunakan metode penghitungan statistik dan algoritma machine learning yaitu Decision Tree, keterlambatan dapat diprediksi sesuai dengan kategori keterlambatan yang tertulis dalam Peraturan Menteri dan premi asuransi dapat dihitung dengan sesuai dan saling menguntungkan kedua belah pihak.

Dalam penelitian ini permasalahan mencakup bagaimana membuat model berbasis web dengan Decision Tree untuk memprediksi keterlambatan penerbangan pada penerbangan komersial di Indonesia dan bagaimana menghitung premi yang sesuai menggunakan metode statistik berdasarkan keterlambatan penerbangan pada penerbangan komersial di Indonesia. Adapun beberapa batasan dalam penelitian ini, yaitu metode yang digunakan untuk memprediksi keterlambatan penerbangan adalah Decision Tree dengan algoritma C5.0, metode yang digunakan untuk menghitung premi asuransi perjalanan adalah metode statistik, data yang diambil berasal dari $w w w$.flightradar24.com, data yang diambil adalah data penerbangan (yang mencakup data maskapai, kota keberangkatan, kota tujuan, tanggal penerbangan, waktu keberangkatan dan tujuan (standard dan actual), dan juga status penerbangan) komersial di Indonesia pada tanggal 18 Juni 2017 sampai 4 Juli 2019 yang meliputi 8 maskapai penerbangan di Indonesia yaitu Lion Air, Garuda Indonesia, Batik Air, Citilink, Sriwijaya, Wings Air, NAM Air, dan Express Air, implementasi metode untuk memprediksi dan menghitung premi akan menggunakan bahasa pemrograman $\mathrm{R}$, teknik evaluasi akan menggunakan confusion matrix, dan hasil yang ditampilkan berupa aplikasi berbasis web yang dibuat menggunakan package $R$ Shiny. Tujuan utama dari penelitian ini adalah merancang sebuah model yang dapat memprediksi keterlambatan penerbangan pada penerbangan komersial di Indonesia. Hasil dari prediksi tersebut akan digunakan sebagai acuan dalam menghitung premi asuransi perjalanan untuk setiap penerbangan. Informasi mengenai premi asuransi perjalanan ini dapat digunakan untuk menentukan biaya yang harus dikeluarkan oleh penumpang penerbangan komersial di Indonesia saat melakukan pembelian tiket perjalanan.

\section{LANDASAN TEORI}

Pada bagian ini akan dibahas landasan teori yang digunakan dalam penelitian ini yang meliputi premi asuransi, penghitungan premi asuransi perjalanan, dan decision tree. 


\subsection{Premi Asuransi}

Premi asuransi adalah sejumlah uang yang dibayarkan baik oleh individu maupun perusahaan yang dikeluarkan untuk membayar biaya polis asuransi selama beberapa periode tertentu [4]. Premi asuransi dibayarkan untuk polis yang mencakup perawatan kesehatan, mobil, rumah, maupun jiwa [5]. Setelah dibayarkan, premi merupakan pendapatan bagi perusahaan asuransi. Namun, selain menjadi pendapatan, premi juga merupakan kewajiban, karena perusahaan asuransi harus memberikan pertanggungan untuk klaim yang dibuat berdasarkan polis asuransi. Kegagalan membayar premi asuransi akan menyebabkan pembatalan terhadap polis asuransi.

\subsection{Penghitungan Premi Asuransi Perjalanan}

Terdapat beberapa langkah untuk menghitung premi asuransi menggunakan metode statistik khususnya standar deviasi. Pertama, tentukan airline yang preminya akan dihitung. Kedua, tentukan kota keberangkatan. Kemudian yang terakhir adalah menghitung premi. Terdapat dua variabel yang dibutuhkan untuk menghitung delay, yaitu rata-rata dari kerugian setiap penumpang yang menggunakan airline tersebut yang disimpan pada variabel mean, dan total kerugian dari setiap airline yang disimpan pada variabel Tloss [6].

$$
\begin{aligned}
& \text { Tloss }=\sum_{i=1}^{5} N(i) * \operatorname{loss}(i) \\
& \text { Mean }=\text { Tloss } / \text { Passengers }
\end{aligned}
$$

Total kerugian (Tloss) dapat dihitung dengan persamaan (1) dan rata-rata (Mean) dapat dihitung dengan persamaan (2). N (1) menunjukkan jumlah penumpang yang memiliki delay code dan loss adalah kompensasi untuk penumpang yang mengalami delay. Huruf i mewakili tipe delay $0,1,2,3,4,5$ dan Passengers (2) adalah total jumlah penumpang.

Perusahaan asuransi bertanggung jawab untuk memberikan kompensasi dengan mencakup semua kerugian. Secara ideal, total premi bernilai sama dengan total kerugian, sehingga nilai premi yang didapatkan tidak terlalu merugikan bagi penumpang dan tidak terlalu menguntungkan bagi pihak maskapai. Namun, hal itu tidak berjalan demikian di dalam dunia bisnis.

$$
\begin{array}{r}
\text { Premium }=\mu+\sigma \\
\mu=\sum_{i=0}^{5} \operatorname{loss}(i) \times p(i) \\
\sigma=\sqrt{\sum_{i=0}^{5}(\operatorname{loss}(i)-\mu)^{2} \times p(i)}
\end{array}
$$

$$
p(i)=\frac{f(i)}{\sum_{i=0}^{5} f(i)}
$$

Premi dihitung berdasarkan rata-rata (mean) dan standar deviasi kerugian, yang dapat dilihat pada persamaan (3). Mean dan standar deviasi dihitung dengan persamaan (4) dan (5). Kemungkinan dari setiap kode delay dihitung dengan persamaan (6) dan disimpan pada variabel $p(i)(6)$, sedangkan $f(i)$ adalah jumlah penumpang yang berangkat dari suatu kota dengan penerbangan yang memiliki tipe delay i. Berdasarkan hasil penghitungan premi asuransi yang dilakukan, terdapat kemungkinan untuk meningkatkan keuntungan penumpang ketika terjadi delay. Banyak kemungkinan yang dapat ditawarkan untuk keuntungan penumpang namun terdapat beberapa pertimbangan yang harus dipenuhi yaitu:

1. Total kerugian harus lebih rendah dari total premi. Idealnya total premi sama dengan total kerugian.

2. Nilai premi pada tipe delay 1, 2, 3, 4 harus ditingkatkan untuk menarik penumpang membeli asuransi.

\subsection{Decision Tree}

Decision Tree adalah salah satu metode dalam machine learning yang digunakan baik untuk klasifikasi maupun regresi (Rokach dan Maimon, 2008). Tujuan dari metode ini adalah untuk membuat model yang memprediksi nilai variabel target atau sering disebut sebagai dependent variable berdasarkan beberapa variabel input atau independent variable. Decision Tree dapat membantu untuk mengidentifikasi strategi mana yang paling cocok untuk mencapai tujuan. Metode Decision Tree yang digunakan untuk melakukan klasifikasi, disebut sebagai pohon klasifikasi. Sedangkan metode Decision Tree yang digunakan untuk melakukan regresi, disebut sebagai pohon regresi.

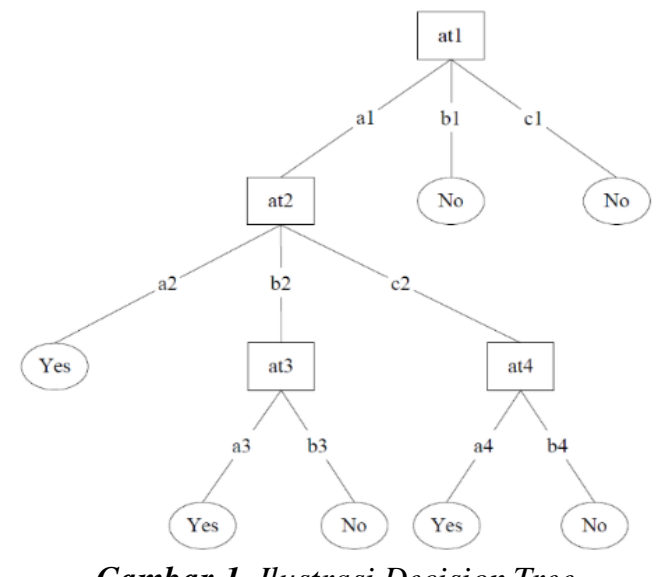

Gambar 1 Ilustrasi Decision Tree 
Ilustrasi Decision Tree dapat dilihat pada Gambar 1. Ilustrasi tersebut menggunakan data training dengan menggunakan data yang terdapat pada Tabel 1. Pada Gambar 1 , dapat dilihat data at $1=\mathrm{a} 1$, at $2=\mathrm{b} 2$, at $3=\mathrm{a} 3$, at4=b4 akan melakukan pemilihan terhadap node at1, at2, dan kemudian at3, yang akan melakukan proses klasifikasi dengan hasil "yes" atau "no" [7].

\section{Tabel 1 Ilustrasi Data Training}

\begin{tabular}{|c|c|c|c|c|}
\hline at1 & at2 & at3 & at4 & Class \\
\hline $\mathrm{a} 1$ & $\mathrm{a} 2$ & $\mathrm{a} 3$ & $\mathrm{a} 4$ & Yes \\
\hline $\mathrm{a} 1$ & $\mathrm{a} 2$ & $\mathrm{a} 3$ & $\mathrm{~b} 4$ & $Y e s$ \\
\hline $\mathrm{a} 1$ & $\mathrm{~b} 2$ & $\mathrm{a} 3$ & $\mathrm{a} 4$ & $Y$ Ses \\
\hline $\mathrm{a} 1$ & $\mathrm{~b} 2$ & $\mathrm{~b} 3$ & $\mathrm{~b} 4$ & No \\
\hline $\mathrm{a} 1$ & $\mathrm{c} 2$ & $\mathrm{a} 3$ & $\mathrm{a} 4$ & $Y$ Ses \\
\hline $\mathrm{a} 1$ & $\mathrm{c} 2$ & $\mathrm{a} 3$ & $\mathrm{~b} 4$ & No \\
\hline $\mathrm{b} 1$ & $\mathrm{~b} 2$ & $\mathrm{~b} 3$ & $\mathrm{~b} 4$ & No \\
\hline $\mathrm{c} 1$ & $\mathrm{~b} 2$ & $\mathrm{~b} 3$ & $\mathrm{~b} 4$ & No \\
\hline
\end{tabular}

Decision Tree memiliki banyak algoritma yang dapat digunakan untuk membuat model decision tree tersebut. Beberapa algoritma yang populer digunakan adalah ID3, C4.5/C5.0, CART, CHAID, dan MARS. Setiap algoritma memiliki perbedaan dalam penggunaan metrik dalam mengukur pembagian yang terbaik [8].

\section{METODOLOGI PENELITIAN}

Tahap perancangan sistem adalah sebagai berikut: membaca raw data penerbangan komersial di Indonesia dari tahun 2017 sampai 2019, data preprocessing, data cleansing, data training, prediction process, dan premium calculation.

\subsection{Raw Data}

Raw data atau data mentah yang diambil dari www.flightradar24.com merupakan data penerbangan komersial di Indonesia selama kurang lebih 2 tahun dari tanggal 18 Juni 2017 sampai dengan 4 Juli 2019. Data yang diambil merupakan data penerbangan dari 8 maskapai di Indonesia yaitu, Lion Air, Garuda Indonesia, Batik Air, Citilink, Sriwijaya, Wings Air, NAM Air, dan Express Air. Himpunan data penerbangan tersebut memiliki 1.019 .557 records dengan format file Excel Workbook $(x l s x)$. Atribut-atribut yang ada di dalam himpunan data penerbangan tersebut dapat dilihat pada Tabel 2.

Tabel 2 Atribut Raw Data

\begin{tabular}{|l|l|l|}
\hline \multicolumn{1}{|c|}{ Nama } & \multicolumn{1}{c|}{ Deskripsi } & \multicolumn{1}{c|}{ Contoh } \\
\hline Date & Tanggal keberangkatan & $5 / 22 / 2019$ \\
& & $12 / 8 / 2018$ \\
\hline From & Kota keberangkatan & Jakarta (CGK) \\
& & Yogyakarta (JOG) \\
\hline To & Kota tujuan & Samarinda (SRI) \\
& & Jambi (DJB) \\
\hline Flight & Nomor penerbangan & ID7281 \\
& & GA266 \\
\hline Flight Time & Lama penerbangan & $0: 36$ \\
\hline
\end{tabular}

Copyright $(2020$ FT-UHAMKA. - All rights reserved DOI: 10.22236/teknoka.v5i.326

\begin{tabular}{|l|l|l|}
\hline & & $0: 49$ \\
\hline STD & Scheduled Time of Departure (waktu & $12: 00: 00 \mathrm{AM}$ \\
& keberangkatan yang dijadwalkan) & $6: 25: 00 \mathrm{AM}$ \\
\hline ATD & Actual Time of Departure (waktu & $11: 59: 00 \mathrm{PM}$ \\
& keberangkatan yang sebenarnya) & $4: 58: 00 \mathrm{AM}$ \\
\hline STA & Standard Time of Arrival (waktu & $12: 40 \mathrm{AM}$ \\
& kedatangan) & $1: 05 \mathrm{AM}$ \\
\hline Status & Keterangan status penerbangan & Landed $12: 36 \mathrm{AM}$ \\
& & Landed $1: 18 \mathrm{AM}$ \\
\hline Airlines & Nama maskapai & Citilink \\
& & Sriwijaya \\
\hline
\end{tabular}

Pada setiap maskapai yang ada di dalam himpunan data penerbangan tersebut, terdapat jumlah records yang berbeda-beda. Jumlah records untuk setiap maskapai dapat dilihat pada Tabel 3. Himpunan data tersebut memiliki 1.798 unik penerbangan dengan kombinasi airline-from-to.

Tabel 3 Jumlah Records Setiap Maskapai

\begin{tabular}{|l|l|}
\hline \multicolumn{1}{|c|}{ Maskapai } & \multicolumn{1}{|c|}{ Records } \\
\hline Lion Air & 324701 \\
\hline Garuda Indonesia & 271637 \\
\hline Batik Air & 122006 \\
\hline Citilink & 168929 \\
\hline Sriwijaya Air & 65678 \\
\hline NAM Air & 15001 \\
\hline XPRESS Air & 839 \\
\hline WINGS Air & 50266 \\
\hline
\end{tabular}

Namun, himpunan data penerbangan tersebut tidak dapat langsung digunakan untuk melakukan proses prediksi dikarenakan kurangnya atribut yang dibutuhkan. Oleh karena itu, perlu dilakukan pengolahan data lebih lanjut atau data preprocessing dan juga pembersihan data atau data cleansing.

\subsection{Data Preprocessing}

Atribut tambahan yang diperlukan dapat dilihat pada Tabel 4. Atribut-atribut tambahan tersebut dapat diperoleh dengan cara memanfaatkan atribut yang sudah ada. Oleh karena itu, perlu dilakukan pengolahan data atau data preprocessing untuk melengkapi himpunan data penerbangan tersebut.

Tabel 4 Atribut Tambahan

\begin{tabular}{|l|l|l|}
\hline \multicolumn{1}{|c|}{$\begin{array}{c}\text { Nama } \\
\text { Atribut }\end{array}$} & \multicolumn{1}{|c|}{ Deskripsi } & Format dan Contoh \\
\hline TrueDelay & Total waktu keterlambatan & Didapatkan dengan cara \\
& dalam satuan menit & ATD \\
& & Contoh: 173,35 \\
\hline DelayType & Kategori keterlambatan & $0=$ tidak delay \\
& berdasarkan total waktu & $1=30-60$ menit delay \\
& (TrueDelay) & $2=61-120$ menit delay \\
& & $3=121-180$ menit delay \\
& & $4=181-240$ menit delay \\
& & $5=>240$ menit delay \\
\hline Bdelay & Binary delay & $0=$ DelayType bernilai 0 \\
& & $1=$ DelayType bernilai $1-5$ \\
\hline Day & Nama hari penerbangan & $1=$ Minggu \\
& & $2=$ Senin \\
& & $3=$ Selasa \\
& & $4=$ Rabu \\
& & $5=$ Kamis \\
& & $6=$ Jumat \\
& & $7=$ Sabtu \\
\hline
\end{tabular}
ISSNNo. 2502-8782 


\begin{tabular}{|l|l|l|}
\hline DeparType & $\begin{array}{l}\text { Kategori waktu penerbangan } \\
\text { terjadwal (STD) berdasarkan } \\
\text { pembagian waktu dalam satu } \\
\text { hari }\end{array}$ & $\begin{array}{l}\text { Early Morning }=00: 00-5: 59 \\
\text { Morning }=6: 00-11: 59 \\
\text { Afternoon }=12: 00-17: 59 \\
\text { Night }=18: 00-23: 59\end{array}$ \\
\hline NumPass & Jumlah penumpang di dalam & Didapatkan dengan cara \\
& satu Penerbangan & mengeluarkan angka acak \\
& & dengan range 80\%-100\% dari \\
& & kapasitas maksimum. (Data \\
& kapasitas maksimum dapat \\
& & dilihat pada Tabel 5) \\
& & Contoh: 138,166,116 \\
\hline
\end{tabular}

Tabel 5 Jumlah Kapasitas Maksimum Setiap Maskapai

\begin{tabular}{|l|l|}
\hline \multicolumn{1}{|c|}{ Maskapai } & Kapasitas Maksimum \\
\hline Lion Air & 189 \\
\hline Garuda Indonesia & 140 \\
\hline Batik Air & 166 \\
\hline Citilink & 166 \\
\hline Sriwijaya Air & 153 \\
\hline NAM Air & 120 \\
\hline XPRESS Air & 128 \\
\hline WINGS Air & 72 \\
\hline
\end{tabular}

\subsection{Data Cleansing}

Data cleansing dilakukan untuk menghilangkan data-data yang tidak valid atau tidak dapat digunakan untuk melakukan data training. Raw data penerbangan yang tersedia memiliki 1.019 .557 records yang terdiri dari 8 maskapai, 115 kota keberangkatan, dan 119 kota tujuan. Kriteria dari pembersihan data ini adalah setiap penerbangan untuk satu maskapai, satu kota keberangkatan, dan satu kota tujuan harus memiliki sekurang-kurangnya 104 penerbangan dengan asumsi memiliki paling sedikit satu kali penerbangan dalam satu minggu. Oleh karena itu, perlu dilakukan pengelompokan data berdasarkan maskapai, kota keberangkatan, dan kota tujuan. Proses data cleansing yang dilakukan akan sekaligus digunakan untuk mendapatkan satu atribut yang menyimpan nilai delay atau tidak delay berdasarkan perbandingan banyaknya jumlah penerbangan yang delay dan tidak delay. Atribut tersebut akan digunakan pada tahap berikutnya yaitu proses validasi. Atribut-atribut yang diperlukan untuk melakukan proses data cleansing terdapat pada Tabel 6 .

Tabel 6 Atribut Pada Data Cleansing

\begin{tabular}{|l|l|l|}
\hline \multicolumn{1}{|c|}{$\begin{array}{c}\text { Nama } \\
\text { Atribut }\end{array}$} & \multicolumn{1}{|c|}{ Deskripsi } & Format dan Contoh \\
\hline Airlines & Nama maskapai & $\begin{array}{l}\text { Citilink } \\
\text { Garuda Indonesia }\end{array}$ \\
\hline From & Kota keberangkatan & $\begin{array}{l}\text { Jakarta (HLP) } \\
\text { Semarang (SRG) }\end{array}$ \\
\hline To & Kota tujuan & $\begin{array}{l}\text { Samarinda (SRI) } \\
\text { Denpasar (DPS) }\end{array}$ \\
\hline sum0 & Total penerbangan yang & 273 \\
& memiliki DelayType dengan tipe & 179 \\
& 0 & \\
\hline sum1 & $\begin{array}{l}\text { Total penerbangan yang } \\
\text { memiliki }\end{array}$ & 26 \\
& DelayType dengan tipe 1 & 45 \\
\hline sum2 & $\begin{array}{l}\text { Total penerbangan yang } \\
\text { memiliki } \\
\text { DelayType dengan tipe 2 }\end{array}$ & 7 \\
& $\begin{array}{l}\text { Total penerbangan yang } \\
\text { memiliki } \\
\text { DelayType dengan tipe 3 }\end{array}$ & 22 \\
\hline sum3 & & \\
& & 29 \\
& & \\
\hline
\end{tabular}

\begin{tabular}{|c|c|c|}
\hline sum 4 & $\begin{array}{l}\text { Total penerbangan yang } \\
\text { memiliki } \\
\text { DelayType dengan tipe } 4\end{array}$ & $\begin{array}{l}3 \\
28\end{array}$ \\
\hline sum5 & $\begin{array}{l}\text { Total penerbangan yang } \\
\text { memiliki } \\
\text { DelayType dengan tipe } 5\end{array}$ & $\begin{array}{l}110 \\
12\end{array}$ \\
\hline$\overline{\text { Total_Flight }}$ & Total penerbangan keseluruhan & $\begin{array}{l}626 \\
4673 \\
\end{array}$ \\
\hline Total_Delay & $\begin{array}{l}\text { Total penerbangan yang } \\
\text { mengalami delay. DelayType } \\
\text { bernilai } 1-5\end{array}$ & $\begin{array}{l}\text { Menjumlahkan sum1 } \\
\text { sampai sum5. } \\
\text { Contoh: } 104,34,61\end{array}$ \\
\hline code_delay & Nilai delay atau tidak delay & $\begin{array}{l}0=\text { sum } 0>\text { Total_Delay } \\
1=\text { sum } 0 \leq \text { Total_Delay }\end{array}$ \\
\hline is_deleted & $\begin{array}{l}\text { Nilai apakah data tersebut akan } \\
\text { dihapus atau tidak }\end{array}$ & $\begin{array}{l}0=\text { Total_Flight } \geq 104 \\
1=\text { Total_Flight }<104\end{array}$ \\
\hline
\end{tabular}

\subsection{Data Training}

Setelah melalui tahap data cleansing, himpunan data penerbangan memiliki 990.321 records yang terdiri dari 5 maskapai, 81 kota keberangkatan, dan 90 kota tujuan. Data yang telah melewati tahap data cleansing telah dapat digunakan untuk melakukan data training. Dalam melakukan data training, diperlukan suatu data frame yang berisi variable independent dan variable dependent. Variable independent terdiri dari Airlines, From, To, Day, dan DeparType. Kemudian variable dependent adalah Bdelay.

\subsection{Prediction Process}

Langkah pertama dalam melakukan prediksi adalah dengan cara membuat model machine learning menggunakan data training yang sudah dimiliki. Pembuatan model machine learning ini menggunakan metode decision tree dengan algoritma C5.0. Fungsi yang digunakan untuk pembuatan model decision tree terdapat pada library $\mathrm{C} 5.0$

\subsection{Premium Calculation}

Pada proses penghitungan premi, terdapat 2 penghitungan yang dilakukan. Penghitungan pertama adalah penghitungan premi awal, yaitu premi yang dihitung menggunakan persamaan (3) sampai (6) diatas dengan menggunakan harga kompensasi awal. Penghitungan kedua adalah penghitungan premi baru, yaitu premi yang dihitung menggunakan persamaan (7) dengan menggunakan harga kompensasi baru. Dalam melakukan penghitungan premi asuransi baru, dibutuhkan himpunan data dengan atribut-atribut pada Tabel 7. Proses pengolahan data untuk menghasilkan himpunan data tersebut dilakukan dengan cara yang serupa dengan proses data cleansing.

Tabel 7 Atribut Himpunan Data Pada Penghitungan Premi

\begin{tabular}{|l|l|l|}
\hline $\begin{array}{c}\text { Nama } \\
\text { Atribut }\end{array}$ & \multicolumn{1}{|c|}{ Deskripsi } & \multicolumn{1}{c|}{$\begin{array}{c}\text { Format dan } \\
\text { Contoh }\end{array}$} \\
\hline Airlines & Nama maskapai & $\begin{array}{l}\text { Citilink } \\
\text { Garuda Indonesia }\end{array}$ \\
\hline From & Kota keberangkatan & Jakarta (HLP) \\
\hline
\end{tabular}

Seminar Nasional TEKNOKA ke - 5, Vol. 5, 2020 ISSNNo. 2502-8782 


\begin{tabular}{|l|l|l|}
\hline & & Semarang (SRG) \\
\hline To & Kota tujuan & Samarinda (SRI) \\
& & Denpasar (DPS) \\
\hline pred0 & Jumlah penumpang dari penerbangan & 87701 \\
& yang terprediksi tidak delay & 216045 \\
\hline pred1 & Jumlah penumpang dari penerbangan & 44523 \\
& yang terprediksi delay & 116086 \\
\hline tloss & Total kerugian yang harus & Didapatkan dengan cara \\
& dikeluarkan oleh maskapai & menjumlahkan hasil dari \\
& & total penumpang dikali \\
& & nilai kompensasi baru, \\
& & yang dikelompokkan \\
& & berdasarkan tipe delay. \\
& \multicolumn{2}{|l}{ Nilai kompensasi dapat } \\
& \multicolumn{2}{|c|}{ dilihat pada Tabel 8 [6]. } \\
& \multicolumn{2}{|c|}{ Contoh: 2.928.460.000 } \\
\hline
\end{tabular}

Tabel 8 Nilai Kompensasi Baru Berdasarkan Tipe Delay

\begin{tabular}{|l|l|l|}
\hline $\begin{array}{c}\text { Tipe } \\
\text { Delay }\end{array}$ & $\begin{array}{c}\text { Lama Delay } \\
\text { (menit) }\end{array}$ & $\begin{array}{c}\text { Kompensasi } \\
\text { (IDR) }\end{array}$ \\
\hline 0 & $0-29$ & 0 \\
\hline 1 & $30-60$ & 50.000 \\
\hline 2 & $61-120$ & 75.000 \\
\hline 3 & $121-180$ & 105.000 \\
\hline 4 & $181-240$ & 150.000 \\
\hline 5 & $>240$ & 450.000 \\
\hline
\end{tabular}

Terdapat dua nilai premi yang akan dihitung pada penghitungan premi baru, yang pertama adalah nilai premi rendah yaitu premi untuk penerbangan yang terprediksi tidak delay (atribut plow), kedua adalah premi tinggi yaitu premi untuk penerbangan yang terprediksi delay (atribut phigh). Nilai premi dapat dicari dengan persamaan (7) dibawah dengan kondisikondisi sebagai berikut:

1) Jika nilai pred0 atau predl bernilai nol, maka plow $=$ phigh .

2) Jika nilai predo dan predl tidak nol, maka nilai plow dan phigh yang diambil adalah nilai yang memiliki selisih terkecil.

$$
(\text { pred } 0 . \text { plow })+(\text { pred1.phigh })=\text { tloss }
$$

Langkah pertama dalam mencari nilai plow dan phigh adalah dengan memberikan nilai 1000 sebagai nilai sementara untuk plow. Setelah itu dilakukan iterasi dengan kelipatan 1000 sampai menemukan selisih plow dan phigh yang terkecil.

\section{HASIL DAN PEMBAHASAN}

Pada bagian ini akan dibahas hasil penelitian yang meliputi hasil prediksi, hasil penghitungan premi dan contoh antar muka aplikasi.

\subsection{Hasil Pre diksi}

Pada Gambar 2 dibawah, cases menjelaskan bahwa terdapat 990.231 data yang di-training, size menunjukkan jumlah leaf nodes decision tree yang terbentuk, yaitu sebanyak 460 nodes, kemudian 269.751 pada bagian errors menunjukkan jumlah records yang salah klasifikasi dan 27,2\% merupakan rasio kesalahan atau error dari keseluruhan records data. Persentase error yang cukup tinggi ini disebabkan oleh adanya atribut-atribut independent variable yang sama namun memiliki label atau Bdelay yang berbeda. Confusion matrix menunjukkan sebanyak 554.178 records data yang tidak delay diklasifikasikan tidak delay (True Positive), 90.384 records data yang tidak delay namun diklasifikasikan delay (False Negative), 179.367 records data yang delay namun diklasifikasikan tidak delay (False Positive), dan 166.302 records data yang delay diklasifikasikan delay (True Negative). Besar akurasi dapat diperoleh dengan cara membagi jumlah nilai True Positive dan True Negative atau total records yang terklasifikasi benar dengan total data keseluruhan. Nilai akurasi yang didapatkan dari confusion matrix pada Gambar 2 adalah sebesar $72,76 \%$.

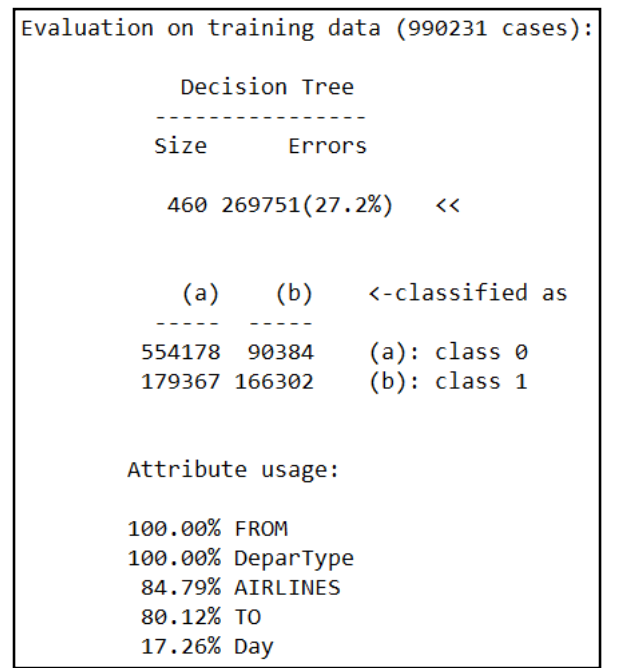

Gambar 2 Ringkasan Evaluasi Data Training

Gambar 2 juga menunjukkan besar persentase atribut-atribut yang digunakan sebagai penentu. Dapat dilihat bahwa atribut From dan DeparType digunakan $100 \%$, diikuti dengan atribut Airlines dengan 84,79\%, kemudian atribut To $80,12 \%$, dan yang terakhir adalah atribut Day dengan 17,26\%. Setelah model diperoleh, prediksi dilakukan. Setelah hasil prediksi dan kelas target (Bdelay) ditambahkan ke dalam data frame kelas input yaitu input_training_set, hasil prediksi pada data frame tersebut dapat dilihat pada Tabel 9.

Tabel 9 Hasil Prediksi

\begin{tabular}{|l|l|l|l|l|l|l|}
\hline Airlines & From & To & $\begin{array}{l}\text { D } \\
\boldsymbol{a} \\
\end{array}$ & $\begin{array}{l}\text { Depar } \\
\text { Type }\end{array}$ & Bdelay & $\begin{array}{l}\text { Predi } \\
\text { ction }\end{array}$ \\
\hline Lion Air & BTH & PLM & 2 & Morning & 0 & 1 \\
\hline Citilink & HLP & PDG & 7 & Afternoon & 1 & 1 \\
\hline Batik Air & HLP & AMQ & 2 & Night & 1 & 0 \\
\hline WINGS & BMU & LOP & 5 & Night & 0 & 0 \\
\hline
\end{tabular}


Pada Tabel 9 dapat dilihat bahwa penerbangan dengan maskapai Lion Air, dari kota Batam (BTH) menuju kota Palembang (PLM), pada hari Senin dengan kategori waktu keberangkatan pagi hari mendapatkan hasil prediksi delay sedangkan pada data aktual penerbangan yang diwakili dengan atribut Bdelay menunjukkan bahwa penerbangan tersebut tidak delay. Setelah mendapatkan hasil prediksi, perlu dilakukan pengecekan kembali terhadap hasil prediksi tersebut, hal ini dapat dikatakan sebagai proses validasi, proses ini dilakukan dengan cara membandingkan hasil prediksi dengan suatu atribut untuk menentukan delay atau tidak delay dengan cara membandingkan banyaknya jumlah total penerbangan yang delay dan total penerbangan yang tidak delay, atribut ini dinamakan code_delay seperti yang terlihat pada Tabel 6 diatas. Atribut code_delay yang diperoleh kemudian ditambahkan pada data frame yang sebelumnya digunakan untuk membandingkan hasil prediksi. Tabel 10 dibawah menunjukkan contoh beberapa data penerbangan yang telah ditambahkan dengan atribut code_delay.

Tabel 10 Data Hasil Validasi

\begin{tabular}{|l|l|l|l|l|l|l|l|}
\hline $\begin{array}{l}\text { Air } \\
\text { lines }\end{array}$ & From & To & $\begin{array}{l}\text { D } \\
\boldsymbol{a} \\
\text { Depar }\end{array}$ & $\begin{array}{l}\text { B } \\
\text { Tel }\end{array}$ & $\begin{array}{l}\text { Pre } \\
\text { dicti } \\
\text { on }\end{array}$ & $\begin{array}{l}\text { code_ } \\
\text { delay }\end{array}$ \\
\hline WINGS & KNO & GNS & 4 & Afternoon & 0 & 1 & 0 \\
\hline Lion & BTH & PLM & 2 & Morning & 0 & 1 & 1 \\
\hline Citilink & HLP & PDG & 7 & Afternoon & 1 & 1 & 0 \\
\hline GA & CGK & PKU & 6 & Morning & 1 & 1 & 1 \\
\hline
\end{tabular}

Tabel 10 memperlihatkan penerbangan dengan maskapai WINGS Air, dari kota Medan (KNO) menuju kota Gunung Sitoli (GNS), pada hari Rabu, dengan kategori waktu keberangkatan siang hari, mendapatkan hasil prediksi delay sedangkan pada data aktual penerbangan yang diwakili dengan atribut Bdelay menunjukkan bahwa penerbangan tersebut tidak delay, akan tetapi atribut code_delay menunjukkan angka 0 yang berarti tidak delay, maka dari itu dapat diasumsikan bahwa hasil prediksi pada penerbangan ini kurang tepat. Perbandingan antara hasil prediksi dengan code_delay menunjukkan seberapa tepat hasil prediksi tersebut. Jumlah hasil prediksi yang memiliki nilai yang sama dengan code_delay adalah 951.982 records dari total keseluruhan data. Hal ini membuktikan bahwa hasil prediksi memiliki kesamaan sebesar 96,14\% terhadap code_delay, maka dari itu dapat disimpulkan bahwa hasil prediksi yang telah didapatkan cukup valid.

\subsection{Hasil Penghitungan Premi}

Penghitungan premi meliputi premi awal dan premi baru. Penghitungan premi awal dilakukan dengan menggunakan persamaan (3) sampai (6) dengan harga kompensasi awal yang dapat dilihat pada Tabel 11 (Pemerintah Indonesia, 2015). Hasil penghitungan premi awal dapat dilihat pada Tabel 12 dibawah. Penghitungan premi awal ini menjadi latar belakang mengapa penghitungan premi baru dilakukan. Terdapat total 988 penerbangan yang memiliki nilai premi yang berbeda-beda.

Tabel 11 Nilai Kompensasi Awal

\begin{tabular}{|l|l|l|}
\hline $\begin{array}{c}\text { Tipe } \\
\text { Delay }\end{array}$ & $\begin{array}{c}\text { Lama Delay } \\
\text { (menit) }\end{array}$ & $\begin{array}{c}\text { Kompensasi } \\
\text { (IDR) }\end{array}$ \\
\hline 0 & $0-29$ & 0 \\
\hline 1 & $30-60$ & 10.000 \\
\hline 2 & $61-120$ & 25.000 \\
\hline 3 & $121-180$ & 35.000 \\
\hline 4 & $181-240$ & 50.000 \\
\hline 5 & $>240$ & 300.000 \\
\hline
\end{tabular}

Tabel 12 Hasil Penghitungan Premi Awal

\begin{tabular}{|c|c|c|c|c|c|c|c|}
\hline \multirow{2}{*}{ Airlines } & \multirow{2}{*}{ From } & \multirow{2}{*}{ To } & \multicolumn{5}{|c|}{ Totml Fossenger per DelarThpe } \\
\hline & & & 0 & 1 & 2 & 3 & 4 \\
\hline Citilink & $\mathrm{CGK}$ & KNo & 367850 & 102028 & 47287 & 4334 & 1472 \\
\hline Lion Air & DPS & CGK & 326277 & 256313 & 209580 & 86918 & 29749 \\
\hline Sriwiiara & CGK & $\mathrm{MLG}$ & 96959 & 52808 & 35129 & 8759 & 1392 \\
\hline
\end{tabular}

\begin{tabular}{|c|c|c|c|c|c|}
\hline 5 & Totnl_loss & Mean & Stev & Premium & $\begin{array}{l}\text { Ton:- } \\
\text { Premium (IDR) }\end{array}$ \\
\hline 13697 & $6.536 .845 \mathrm{~K}$ & $12.180,43$ & $47,323,10$ & $59.503,52$ & $31.933 .636 .014,44$ \\
\hline 14024 & $16.539 .410 \mathrm{~K}$ & 17.92189 & $37.578,44$ & 55.500 .33 & 51.219090 .338 .91 \\
\hline 538 & $1.943 .870 \mathrm{~K}$ & 9.938 .75 & 18.991 .98 & $28.930,72$ & 5.658 .415 .752 .86 \\
\hline
\end{tabular}

Tabel 12 menunjukkan bahwa biaya yang harus dikeluarkan oleh maskapai Citilink untuk memberikan kompensasi kepada penumpang yang mengalami delay pada penerbangan dari kota Jakarta (CGK) menuju kota Medan (KNO) adalah IDR 6.536.845.000, biaya ini dapat dilihat pada atribut total_loss. Kemudian premi untuk penerbangan tersebut adalah IDR 59.503,52, sehingga total pemasukan yang didapatkan oleh maskapai Batik Air pada penerbangan tersebut adalah IDR 31.933.636.014,44. Sebagai contoh, dalam penerbangan dengan maskapai Citilink dari kota Jakarta (CGK) menuju kota Medan(KNO), premi asuransi yang ditawarkan kepada penumpang adalah sebesar IDR 59.503,52, tetapi apabila terjadi delay dengan kategori delay tipe 1 , penumpang hanya akan mendapatkan kompensasi sebesar IDR 10.000, begitu juga dengan kategori delay tipe 2, penumpang hanya akan mendapatkan kompensasi sebesar IDR 25.000 padahal penumpang tersebut membeli premi asuransi dengan harga IDR 59.503,52. Penumpang baru akan mendapatkan keuntungan melalui terjadinya delay ketika mengalami delay dengan kategori delay tipe 5 yaitu IDR 300.000. Hal ini menjadi salah satu alasan mengapa penumpang enggan untuk membeli premi. Hasil penghitungan premi awal menunjukkan bahwa terdapat perbedaan yang sangat signifikan pada total biaya yang harus dikeluarkan untuk memberikan 
kompensasi dan total pendapatan yang didapat dari hasil penjualan premi. Biaya yang harus dikeluarkan untuk memberikan kompensasi kepada penumpang yang mengalami delay cenderung lebih kecil ketimbang biaya yang harus dikeluarkan untuk meningkatkan layanan maskapai agar tidak terjadi delay. Oleh karena itu, perlu dilakukan penghitungan premi baru dengan menggunakan nilai kompensasi yang baru sehingga mendapatkan nilai total_loss yang baru, kemudian nilai total_loss tersebut menjadi dasar dari penghitungan premi baru yang akan dilakukan sehingga nilai total_loss atau biaya yang harus dikeluarkan maskapai akan sama dengan jumlah uang yang didapatkan dari penjualan premi. Penghitungan premi baru dapat dilihat pada Tabel 13.

Tabel 13 Hasil Penghitungan Premi Baru

\begin{tabular}{|l|l|c|c|c|l|}
\hline Airlines & From & To & $\begin{array}{c}\text { plow } \\
(\text { IDR })\end{array}$ & $\begin{array}{c}\text { phigh } \\
(\text { IDR })\end{array}$ & Status \\
\hline Citilink & CGK & KNO & $28.858,52$ & $28.858,52$ & Dapat dijual \\
\hline Lion Air & DPS & CGK & $52.000,00$ & $52.531,84$ & $\begin{array}{l}\text { Tidak dapat } \\
\text { dijual }\end{array}$ \\
\hline Sriwijaya & CGK & MLG & $33.000,00$ & $34.462,71$ & Dapat dijual \\
\hline
\end{tabular}

Pada hasil penghitungan premi baru yang ditunjukan pada Tabel 13, penerbangan dengan maskapai Citilink dari kota Jakarta (CGK) menuju kota Medan (KNO), memiliki nilai premi rendah dan premi tinggi yang sama yaitu sebesar IDR 28.858,52 dan memiliki status dapat dijual karena nilai premi tersebut masih di bawah besar kompensasi pada kategori delay tipe 1 yaitu IDR 50.000. Sedangkan pada penerbangan dengan maskapai Lion Air dari kota Denpasar (DPS) menuju kota Jakarta (CGK), nilai premi rendah yang didapatkan adalah sebesar IDR 52.000 sedangkan nilai premi tinggi yang didapatkan adalah sebesar IDR 52.531,84, dan memiliki status tidak dapat dijual dikarenakan kedua nilai premi tersebut jumlahnya lebih dari besar kompensasi yang akan diterima penumpang ketika mengalami delay dengan kategori delay tipe 1 yaitu IDR 50.000. Dengan nilai premi baru yang telah didapatkan, penumpang mendapatkan keuntungan dengan pembelian premi tersebut. Sebagai contoh, pada penerbangan dengan maskapai Sriwijaya Air dari kota Jakarta (CGK) menuju kota Malang (MLG), nilai premi yang harus dibayarkan penumpang jika penerbangan tersebut terprediksi akan mengalami delay adalah IDR 34.462,71. Ketika delay dengan kategori delay tipe 1 terjadi, penumpang akan mendapatkan kompensasi sebesar IDR 50.000. Hal ini diharapkan dapat membuat penumpang berminat untuk membeli premi asuransi perjalanan yang ditawarkan. Pada pihak maskapai, dengan nilai biaya yang harus dikeluarkan oleh maskapai untuk memberikan kompensasi atau total_loss menjadi sebanding dengan uang yang didapatkan dari hasil penjualan premi, diharapkan pihak maskapai dapat meningkatkan layanan agar tidak terjadi delay dikarenakan biaya yang dikeluarkan untuk memberikan kompensasi kepada penumpang tidaklah sedikit.

\subsection{Antar Muka Aplikasi}

Pada Gambar 3 dibawah ditampilkan antar muka aplikasi yang dibuat meminta input yang terdiri dari variable Airlines, From, To, Day, dan DeparType. Setelah input dimasukkan, aplikasi akan mengeluarkan output berupa titik kota keberangkatan dan kota tujuan; hasil prediksi yaitu Delay atau On Time beserta nilai premi yang dimiliki oleh penerbangan tersebut.

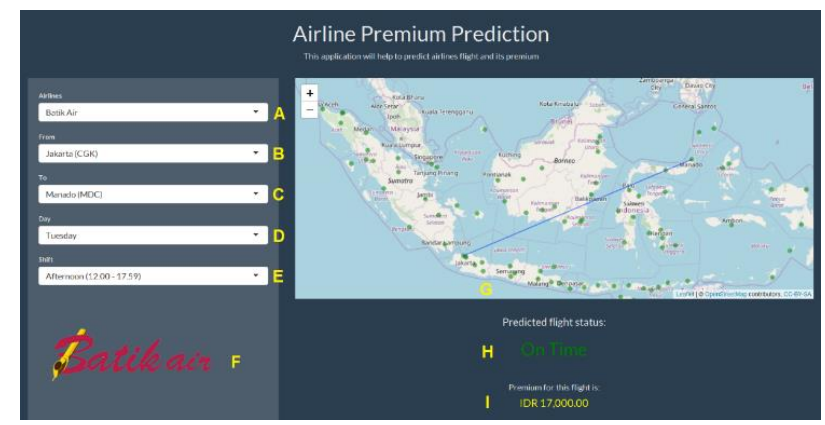

Gambar 3 Antar Muka Aplikasi

\section{SIMPULAN}

Prediksi delay atau keterlambatan penerbangan menggunakan metode decision tree telah berhasil diimplementasikan dengan akurasi sebesar 72,76\% berdasarkan confusion matrix. Kemudian telah dilakukan proses validasi, yaitu proses membandingkan hasil prediksi decision tree dengan prediksi yang didapatkan melalui data historis dengan tingkat kemiripan sebesar 96,14\% sehingga hasil prediksi decision tree yang didapatkan memiliki hasil yang valid. Penghitungan premi baru dengan menggunakan metode statistik juga telah berhasil dilakukan. Hasil nilai premi baru lebih rendah dari hasil nilai premi lama sehingga dapat disimpulkan bahwa nilai premi baru merupakan nilai premi yang lebih masuk akal baik bagi pihak maskapai maupun pihak penumpang.

\section{KEPUSTAKAAN}

[1] Badan Pusat Statistik, Lalu Lintas Penerbangan Dalam Negeri Indonesia Tahun 2003-2018. (2020).

https $/ /$ www.bps.go.id/statictable/2009/02/21/140 2/lalu-lintas-penerbangan-dalam-negeriindonesia-tahun-2003-2018.html. (diakses tanggal 17 Oktober 2020). 
[2] Aviation Safety Network, Airliner Accident Fatalities Per Year 1946-2017. (2017). https://aviation-

safety.net/graphics/infographics/Fatal-AccidentsPer-Year-1946-2017.jpg. (diakses tanggal 17 Oktober 2020).

[3] Pemerintah Indonesia, Peraturan Menteri Perhubungan Republik Indonesia Nomor PM 89 Tahun 2015 Tentang Penanganan Keterlambatan (Delay Management) Pada Badan Usaha Angkutan Udara Niaga Berjadwal di Indonesia. Lembaran RI Tahun 2015 No. 6. Jakarta: Sekretariat Negara. (2015).

[4] Hungelmann, J, Insurancefor dummies, Hoboken, NJ: Wiley. (2009).

[5] Kagan, Julia, Insurance Premium. (2019). https://www.investopedia.com/terms/i/insurancepremium.asp. (diakses tanggal 17 Oktober 2020)
[6] Lukas, S., Margaretha, H., Stefanim D., Widjaja, P., Feng, Ben, Insurance Premium Model For Flight Delay Using Standar Deviation, GLM And SVM. Universitas Pelita Harapan \& University of Waterloo. (2019).

[7] Kotsiantis, S. B., Supervised Machine Learning: A Review of Classification Techniques. Informatica 31, 249-268. (2007).

[8] Rokach, L.; Maimon, O., Top-down induction of decision trees classifiers-a survey. IEEE Transactions on Systems, Man, and Cybernetics Part C: Applications and Reviews, 35 (4): 476$487 . \quad$ CiteSeerX 10.1.1.458.7031. doi:10.1109/TSMCC.2004.843247. (2008). 